\title{
Measuring Sustainable Development at the Lower Regional Level in the Czech Republic based on Composite Indicators
}

\author{
Measuring Sustainable Development in Czech LAU 1 Regions using \\ Composite Indicators
}

\begin{abstract}
Measuring of sustainable development seems to be a great issue as there is neither unified set of indicators nor any preferred methodology how to do it. However, attempts to evaluate entities from the point of view of sustainable development regularly occur. The most problematic level according to sustainable development assessment seems to be "lower" regional level, such as LAU 1 (former NUTS 4) level. On one hand there are usually at this level already serious problems with data availability, on the other hand it is almost impossible to regularly perform detailed questionnaire surveys in all LAU 1 regions ( 77 districts in case of the Czech Republic), as it is done e.g. in cities. The aim of the paper is to decide, how to assess sustainability at this level. Finally we chose useful indicators, though different from indicators used at the national or NUTS 3 level, with data available for all LAU 1 regions. We succeeded in filling all three pillars of sustainable development (economic, social and environmental) with sufficient number of suitable indicators. In the first step we applied cluster analysis to find coherences among regions that are e.g. affected by similar problems. After that we constructed composite indicators in order to create ranking of all 77 districts. Ranking was derived from composite indicator approach. We constructed 10 composite indicators to test different methods of normalisation, weighting and aggregation. The results show the ranking of LAU 1 regions in the Czech Republic from the sustainability point of view, both including and excluding capital city of Prague as an outlying district. A good interconnection between cluster analysis and constructed composite indicators can be seen, which is supported by the discussion of the results.
\end{abstract}

Keywords: Sustainable development indicators, normalisation, weighting and aggregation methods, composite indicators, Czech LAU 1 regions, cluster analysis.

a Department of Economic Statistics, University of Economics in Prague, Nám. W. Churchilla 4, Praha 3, CZ 130 67, Czech Republic. E-mail: lenka.hudrlikova@vse.cz

b Department of Regional Studies, University of Economics in Prague, Nám. W. Churchilla 4, Praha 3, CZ 130 67, Czech Republic. Author is also working in the Czech Statistical Office. E-mail: jana.kramulova@vse.cz

c Department of Economic Statistics, University of Economics in Prague, Nám. W. Churchilla 4, Praha 3, CZ 130 67, Czech Republic. E-mail: janzeman06@gmail.com 


\section{Introduction}

Measuring of sustainable development seems to be a great issue (see e.g. Parris et al., 2003) as there is neither unified set of indicators nor any preferred methodology how to do it. However, attempts to evaluate entities according to sustainable development regularly occur. Especially at the national level various indicators set are being created (e.g. Eurostat has one, see EUROSTAT 2013), as well as at the lowest level for cities (e.g. ECI by European Commission 2013, used in the Czech Republic by TIMUR 2012) or even enterprises. Similarly, at the "higher" regional levels (NUTS 2 and in case of the Czech Republic NUTS 3 level as well) there are also attempts to evaluate sustainability using a set of indicators (Progress Reports on the Czech Republic's Strategic Framework for Sustainable Development). The most problematic level according to sustainable development assessment seems to be "lower" regional level, such as LAU 1 (former NUTS 4) level. At this level there are already serious problems with data availability (i.e. methodological problems of regional GDP estimate or simply non-availability of reliable data). On the other hand it is almost impossible to regularly perform detailed questionnaire surveys in all regions at this level (77 in case of the Czech Republic), as it is done e.g. in case of ECIs. From these reasons it is not possible to use similar approach as in case of "higher" regional level or local level.

This paper is part of our project, which deals with the analysis of sustainable development in the Czech Republic at the regional level (NUTS 3, see e.g. Fischer et al., 2013). In this paper we decided to focus also on the lower level of administrative division on the district level (LAU 1, formerly labelled NUTS 4) - as this level can be seen to be important as well (compare Lengyel et al., 2012). The main aim of the paper is to decide, how to assess sustainability at LAU 1 level. Unfortunately, this level has not been a subject to extensive research in the Czech Republic so far. An interesting approach is applied by Mederly et al. (2004) who analysed sustainability and quality of life in the Czech Republic at three different levels - regional, national and global. However, the regional level was limited exclusively to NUTS 3 level. They chose a huge number of 111 indicators that were initially analysed using correlation analysis and further deeper analysed. Another important approach was employed by the Czech Statistical Office (2010) again at the NUTS 3 level. Together with the Charles University in Prague Environment Centre, they analysed indicators in time series divided into three common pillars of sustainable development economic, social and environmental. Some of these indicators were also used in a strategic document - Progress Reports on the Czech Republic's Strategic Framework for Sustainable Development in the year 2009 (Government Council for Sustainable Development et al. 2009). The new version of this document, published in the year 2012 (Government Council for Sustainable Development et al. 2012), already works with slightly different indicators in a different structure.

As there are no attempts at the LAU 1 level, this paper shows some opportunities, how to assess sustainability at this level. The paper is divided into several sections. The first one deals with the data availability and indicators finally included in the analysis (together with analysis of their correlations). The second section deals with potential coherences among Czech LAU 1 regions, e.g. due to affection by similar problems. Cluster analysis covering all selected indicators was applied to examine this. The third 
section introduces a brief overview of the methodology of composite indicators. Further the methods of normalisation, weighting and aggregation are used for composite indicators construction as well as for subsequent rankings creation. In the fourth section the results are presented and discussed. In the final section main conclusions are outlined.

\section{Sustainable development and set of indicators}

The main idea of sustainable development lies in searching for balance among economic development, social progress and equity and environmental responsibility. The Brundtland Commission definition (WCED, 1987, p. 8) is usually considered to be the main definition broadly accepted. It emphasizes especially the people's needs while expressing that "Humanity has the ability to make development sustainable - to ensure that it meets the needs of the present without compromising the ability of future generations to meet their own needs". However, many other definitions can be found, that bring the discussions on how to really understand the sustainable development and its targets and measurement (for several of them see e.g. Marsden et al. 2010, Byrch et al. 2009, Ciegis et al. 2009, Rassafi et al. 2006, Macháček 2004, p. 28-29 or Nováček et al. 1996, p. 16-19).

We focused on the Czech Republic as a case study. There are 77 districts (i.e. LAU 1 regions) in the Czech Republic including the capital city of Prague, which is very specific among other districts because it is not only a district (LAU 1), but at the same time also a region (NUTS 3) and even NUTS 2 unit. This is not so common in other countries, although capital cities often form a specific region with unusual characteristics. Usually the higher the level of classification, the broader area of the city is included (i.e. with suburban areas which have different characteristics from the core city). Cambridge Econometrics (2013) state that "In general, NUTS 3 regions are used to define the cities, in recognition of the fact that many cities are essentially spatially-concentrated cores of economic interaction which are smaller than NUTS 2 regions, with the important exceptions of the major conurbations such as Paris and London". For example London ${ }^{\mathrm{d}}$ as NUTS 1 is divided into Inner London and Outer London (NUTS 2 regions) and further into five NUTS 3 regions and then into 33 LAU 1 regions. On the other hand in case of Prague the area included in NUTS 2, NUTS 3 and LAU 1 classifications is exactly the same $^{\mathrm{e}}$. Therefore, we decided to perform two types of analysis - including and excluding Prague - and compare the results obtained.

From a statistical point of view and due to the need to meet certain conditions for the use of multivariate methods, the number of 77 units seems to be much more appropriate than the number of 14 regions forming the Czech Republic ${ }^{f}$. This was one of our reasons for focusing on this level. On the other hand the disadvantage of such small territorial units (e.g. districts) consists in the problem of data availability. The problem lies in the fact that each district often follows its own characteristics (indicators), which may differ across districts, or indicators available for some districts are no more available for other districts. According to these findings we were forced to find set of indicators different from the one used in the analysis at the NUTS 3 level (Fischer et al. 2013).

d For more details see Office for National Statistics (2013).

e See Methodology section in Statistical Yearbook of the Czech Republic 2012 (Czech Statistical Office 2012, p. 771)

f Appendix 1 shows map with 77 Czech LAU 1 districts. 


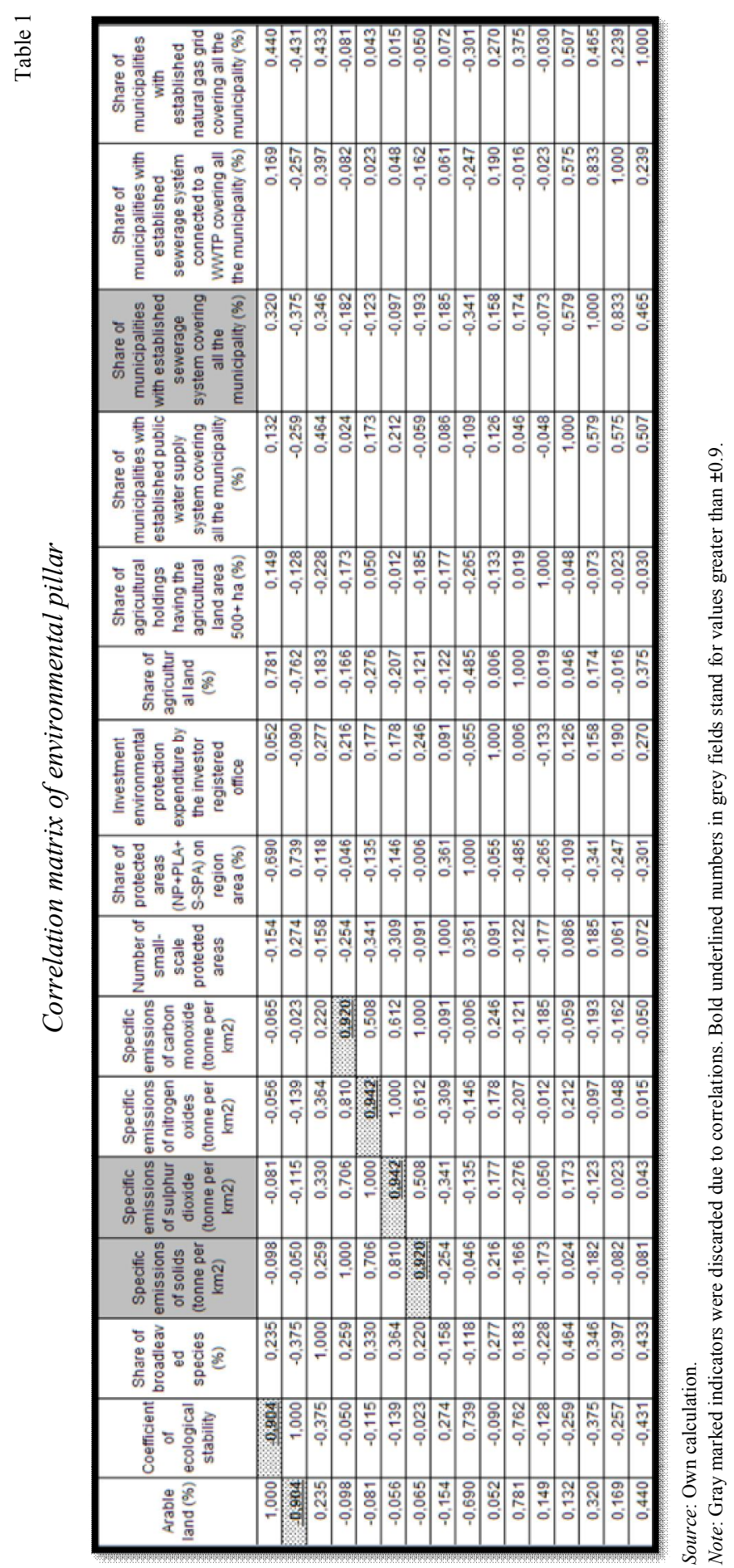


The set of indicators for districts was carefully chosen in order to be the best fitting to the sustainable development issue. It is widely recognized that sustainable development indicators are grouped into (most commonly) three pillars (economic, social and environmental). Part of the indicators chosen for the district level is the same as those used in the analysis of regions, some of them had to be adapted to the available data sources and the rest needed to be newly chosen after the discussions with experts. Our analysis focuses on the year 2010 being the most up-to-date year with data available for all selected indicators. We tried to find all relevant indicators that were available for the district level.

Before starting the main analysis we calculated the correlation matrices for each of the pillars to identify and eliminate redundant indicators (it is needed to pay a great attention to the context and explanation of each indicator in order not to discard the indicators that have a high degree of correlation with indicators which they are not directly related to with). Table 1 below shows correlation matrix of environmental pillar as an example. It contains 16 originally included indicators, 3 of them (two types of emissions and one indicator covering sewerage system) were eliminated according to the results of correlations. The highest (positive) correlation coefficients of 0.942 and 0.920 which lead to elimination of indicators were observed between the different types of emissions (serves as an example of indicators we can discard due to their relationship). On the contrary, high (negative) correlation coefficient of -0.904 was identified between indicators Arable land and Coefficient of ecological stability. As this can be considered as an example of indicators we cannot discard due to their incoherence, both indicators were left in the analysis.

After such adjustments in all three pillars we obtained following set of indicators we are using onwards. While Table 2 shows indicators selected into economic pillar, tables 3 and 4 show indicators in social and environmental pillar.

Table 2

Indicators in economic pillar (13 indicators)

\begin{tabular}{l|l}
\hline EC 1 & Density of motorways and $1^{\text {st }}$ class roads $\left(\mathrm{km}\right.$ per $\left.100 \mathrm{~km}^{2}\right)$ \\
\hline EC 2 & Average value per building notification and/or permit (CZK thousands) \\
\hline EC 3 & Number of entrepreneurs (natural persons and legal persons) per 1000 inhabitants \\
\hline EC 4 & Foreign direct investment for 1000 inhabitants (CZK millions) \\
\hline EC 5 & Number of people receiving unemployment benefit per 100 job applicants \\
\hline EC 6 & Building permits per 1000 inhabitants \\
\hline EC 7 & $\begin{array}{l}\text { Approximate value of construction projects permitted by planning and building control } \\
\text { authorities (CZK millions) }\end{array}$ \\
\hline EC 8 & Domestic construction work "S" (CZK millions, current prices) \\
\hline EC 9 & Operated vehicles (per 1 inhabitant). \\
\hline EC 10 & Number of enterprises with more than 50 employees \\
\hline
\end{tabular}


Indicators in social pillar (17 indicators)

Table 3

\begin{tabular}{l|l}
\hline SO 1 & Total general unemployment rate (\%) \\
\hline SO 2 & Life expectancy at birth (years) \\
\hline SO 3 & Civil society - political participation (turnout in elections to municipal councils in \%) \\
\hline SO 4 & $\begin{array}{l}\text { Women and men in politics (share of women elected representatives in elections to municipal } \\
\text { councils in \%) }\end{array}$ \\
\hline SO 5 & $\begin{array}{l}\text { Civil society - civic participation (number of mid-year population per 1 nongovernmental non- } \\
\text { profit organization) }\end{array}$ \\
\hline SO 6 & Number of job vacancies per 100 applicants \\
\hline SO 7 & Age index (number of inhabitants aged +65 per 100 inhabitants aged 0-14) \\
\hline SO 8 & Share of municipalities with medical facilities (\%) \\
\hline SO 9 & Share of municipalities with school (\%) \\
\hline SO 10 & Average percentage of incapacity for work \\
\hline SO 11 & Average time of sick leave (days) \\
\hline SO 12 & Number of places in social services per 1000 inhabitants \\
\hline SO 13 & Number of doctors per 1000 people (outpatient care) \\
\hline SO 14 & Number of recipients of pensions per 100 inhabitants \\
\hline SO 15 & Average old-age pension (CZK) \\
\hline SO 16 & Number of disabled people-licensee holders per 100 inhabitants \\
\hline SO 17 & Total paid social benefits per 1 inhabitant (CZK) \\
Source: Own compilation based on expert discussion.
\end{tabular}

Indicators in environmental pillar (13 indicators)

Table 4

\begin{tabular}{l|l}
\hline EN 1 & Arable land (\%) \\
\hline EN 2 & Coefficient of ecological stability \\
\hline EN 3 & Share of broadleaved species (\%) \\
\hline EN 4 & Specific emissions of nitrogen oxides (tonne per km2) \\
\hline EN 5 & Specific emissions of carbon monoxide (tonne per km2) \\
\hline EN 6 & Number of small-scale protected areas \\
\hline EN 7 & Share of protected areas (NP + PLA + S - SPA) on region area (\%) \\
\hline EN 8 & Investment environmental protection expenditure by the investor registered office \\
\hline EN 9 & Share of agricultural land (\%) \\
\hline EN 10 & Share of agricultural holdings having the agricultural land area 500+ ha (\%) \\
\hline EN 11 & $\begin{array}{l}\text { Share of municipalities with established public water supply system covering whole } \\
\text { municipality (\%) }\end{array}$ \\
\hline EN 12 & $\begin{array}{l}\text { Share of municipalities with established sewerage system connected to a WWTP covering whole } \\
\text { municipality (\%) }\end{array}$ \\
\hline EN 13 & Share of municipalities with established natural gas grid covering whole municipality (\%) \\
Source: Own compilation based on expert discussion.
\end{tabular}

It is obvious, moving to LAU 1 level means that we can no more work with indicators such as e.g. GDP per capita or labour productivity, which are usually an essential part of the analysis at the higher regional level (NUTS 3 or NUTS 4). This set of indicators represents available but also reliable and relevant data at this level. 


\section{Analysis of similarities among Czech LAU 1 regions}

After selecting the most proper indicators we decided to analyse the similarities in Czech LAU 1 regions according to all 43 indicators without paying attention in which pillar they are incorporated. For this issue we chose one of the multivariate statistical methods - cluster analysis. We tried to group homogenous LAU 1 regions and examine, if such regions with similar problems (e.g. unemployment, structurally affected regions, border regions or highly developed city regions) will belong to the same cluster.

Cluster analysis (Burns et al. 2009, Mooi et al. 2011 or Hebák et al. 2007) is a method of data classification, which performs the division of data into groups that contain units having something in common. The aim of cluster analysis is to divide $n$ LAU 1 regions into $k$ groups, called clusters, using $p$ indicators. Like other types of statistical methods, cluster analysis has several variants which differ in the coalescing process as well; in our case hierarchical clustering is used. We used the Euclidean distance (see Equation (1)) as the distance between two points in the Euclidean space. "Euclidean distance is the most commonly used type when it comes to analyzing ratio or interval-scaled data." (Mooi et al. 2011, p. 245). Mimmack et al. (2001) state that when the cluster analysis is used for defining regions, which is our situation, Euclidean distance seems to be more proper than Mahalanobis distance. Furthermore, Ward's method as one of the methods of joining clusters, used as a linking clusters criterion in the sense of increase of the total intragroup sum of squared deviations of individual observations from the cluster average was applied. Increase is expressed as the sum of squares in the emerging cluster minus the sum of squares in both merging clusters as shown in Equation (2).

$$
\begin{aligned}
& D_{E}\left(x_{i}, x_{i^{\prime}}\right)=\sqrt{\sum_{j=1}^{p}\left(x_{i j}-x_{i^{\prime} j}\right)^{2},} \\
& G=\sum_{h=1}^{k} \sum_{i=1}^{n_{h}} \sum_{j=1}^{p}\left(x_{h i j}-\bar{x}_{h j}\right)^{2},
\end{aligned}
$$

where $G$ stands for Ward's criterion, $k$ stands for number of clusters, $n_{h}$ stands for number of LAU 1 regions in $h^{\text {th }}$ cluster, $p$ stands for number of indicators.

Burns et al. (2009, p. 557) emphasize about Ward's method that "in general, this method is very efficient". Hebák et al. (2007, p. 135) sees another advantage of Ward's method. It forms similarly big cluster when eliminating the small ones.

The same approach (hierarchical clustering with Euclidean distance and Ward's method) was applied e.g. by Odehnal et al. (2012) when evaluating competitiveness of Ukrainian regions. We performed hierarchical clustering within the statistical software NCSS 2007 environment. Based on the results (Figure 1) we agreed on the final number of 6 clusters with the degree of dissimilarity of 6 as a reasonable number. The results of the cluster analysis were captured into individual choropleth maps shown below. It is important to mention that after selecting the indicators and initial data analysis we decided to remove from this analysis the capital city of Prague due to its specifics and incomparableness with other districts. 
Dendrogram as a result of cluster analysis

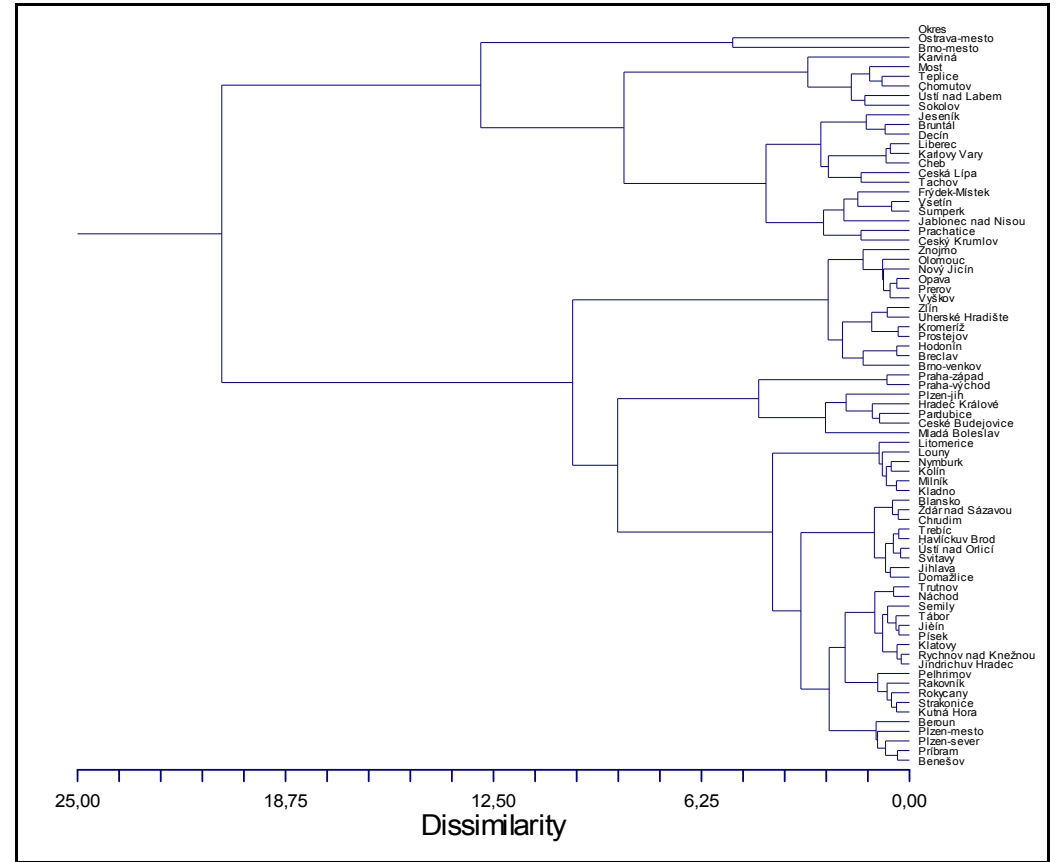

Source: NCSS 2007, own calculation.

Figure 2 shows the clusters in which many similarities can be found. Cluster 1 contains Moravian adjacent districts. Cluster 2 is formed by border districts, mostly situated northwest with one district situated northeast (districts with high unemployment rate). Cluster 3 is the largest cluster, made up of majority of the Czech districts and several Moravian districts. Cluster 4 is composed of 5 sub-clusters which do not have a common border, all of them are border (frontier) districts. Cluster 5 contains districts with medium-sized towns as centres and Prague surroundings. Cluster 6 is made up from the second and the third biggest cities in the Czech Republic (Brno and Ostrava). As mentioned above Prague as a "district-outlier" was discarded from this analysis. If left in analysis, Prague would form separate Cluster 7. 


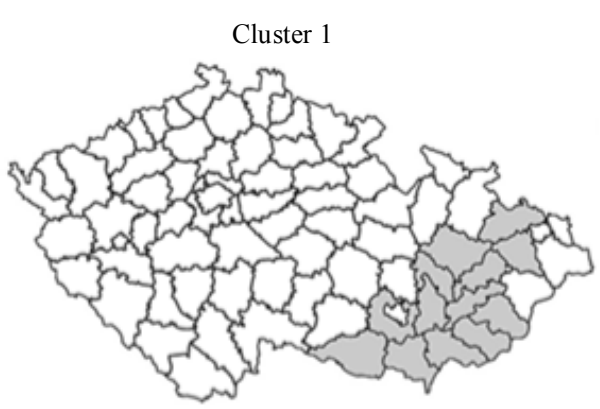

Cluster 3

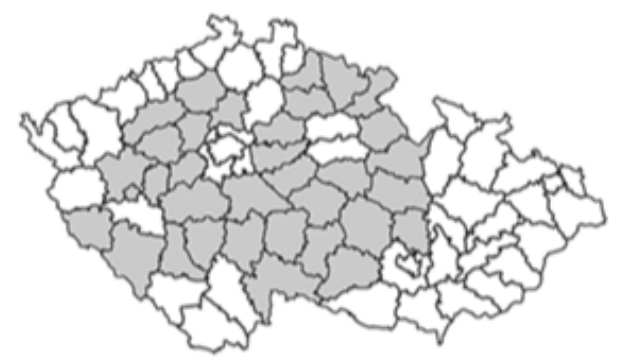

Cluster 5

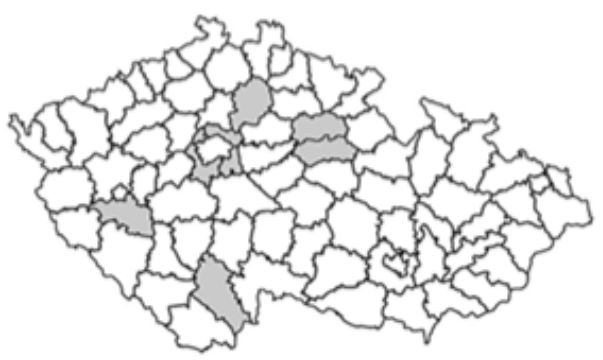

Source: Own analysis in Maps Generator environment.

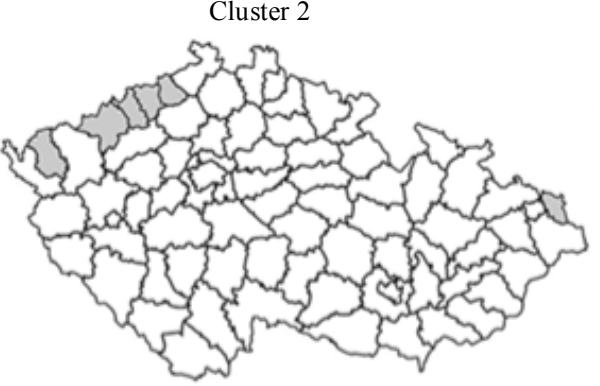

Cluster 4

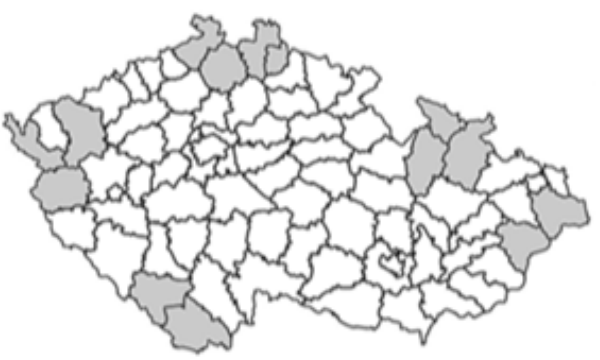

Cluster 6

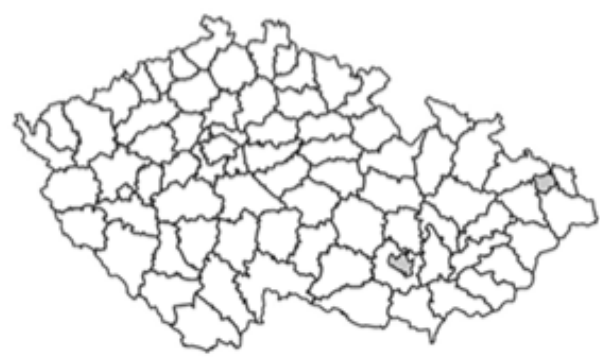

To sum up, Figure 2 shows six clusters whose districts really have similar characteristics (not only in statistical sense, but also in the sense of sustainable development indicators), as Moravian districts, Czech districts, border districts, districts with big cities, or medium-sized towns. These conclusions encouraged us to continue in our analysis with the aim of evaluation of 77 Czech LAU 1 regions. In the next section we will already handle with indicators divided into pillars. 


\section{Methodology of composite indicators}

Composite indicator (CI) is considered to be a useful tool for ranking. Overview of advantages and disadvantages of using composite indicators for sustainable development evaluation is done e.g. in Czesaný (2006). Examples of several CIs for assessment of sustainable development are listed in Parris et al. (2003). It allows expressing a multidimensional issue by one single number. We followed the generally accepted definition of sustainable development stating three areas - economic, environmental and social. Therefore aggregation needed to be performed in two steps. In the first step we aggregated indicators in each separate pillar. The second step consisted in merging all three pillars into one composite indicator. This chosen approach brought three main issues to be solved: method of transformation/normalization of the data, selection of suitable weighting scheme and finally selection of aggregation method.

As in most fields of economic reality also in sustainable development indicators are neither measured in the same units nor have the same direction. Higher values do not always reflect better performance. In other words higher value of an indicator may represent a worse performance (e.g. unemployment). Due to aforementioned reasons certain data transformation is required prior to the next analysis. The goal of the data transformation can be seen in adjustment for different ranges, different variances and outliers. There is a wide scale of normalization methods discussed e.g. in Nardo et al. (2009). Choosing the most appropriate method for normalization is crucial and depends not only on the type of data, but also on weighting and subsequent aggregation. Application of normalization can result in different outcomes for the CI. This paper deals with the two most common types: min-max method and z-scores.

The first considered transformation method is called min-max. Equation (3) is used for indicators for which the higher value the better, equation (4) for indicators for which the lower value the better.

$$
\begin{aligned}
I_{p n} & =\frac{x_{p n}-\min _{n}\left(x_{p}\right)}{\max _{n}\left(x_{p n}\right)-\min _{n}\left(x_{p}\right)}, \\
I_{p n} & =\frac{\max _{n}\left(x_{p}\right)-x_{p n}}{\max _{n}\left(x_{p n}\right)-\min _{n}\left(x_{p}\right)},
\end{aligned}
$$

where $x_{p n}$ is the value of an indicator $p$ for district $n$. Min-max method is based on minimum and maximum values. The advantage lies in the fact that the boundaries can be set and all indicators then get an identical range $(0,1)$. Each indicator reaches value between 0 and 1 even if it is the extreme value. The output is dimensionless and the relative distances remain. Nevertheless, the drawback reveals if outliers and/or extreme values are present. The computation of min-max method is based on extreme values (the minimum and the maximum) which can be outliers. These two values strongly influence the final output (see equations (3) and (4)). Still min-max approach is very popular and has been applied for construction of many composite indicators, e.g. the well-known Human Development Index (HDI), issued by the United Nations (Klugman 2011).

The second normalization method (z-scores) converts the data in order to have a common scale with a zero mean and standard deviation of one. For each indicator $x_{p n}$ the 
average across districts $x_{p n}=\bar{n}$ and standard deviation across districts $\sigma_{p n}^{\prime}=\bar{n}$ are calculated and used in formula (5).

$$
I_{p n}=\frac{x_{p n}-x_{p n=\pi}}{\sigma_{p n=\pi}^{\prime}},
$$

This method provides no distortion from the mean; it adjusts different scales and different variance. The output is again dimensionless and because of applying of a linear transformation the relative differences can preserve. Z-scores method does not fully adjust for outliers. An indicator with extreme value has a greater effect on a composite indicator. This is desirable if exceptional behaviour should be rewarded, i.e. if an excellent performance on a few indicators is considered to be better than a lot of average performances. However, this effect can be reduced by applying proper aggregation method. Compared to min-max method, z-scores method is even more robust on outliers because it is based on variance instead of the range.

Weighting as the second step has a crucial effect on the outcome of the CI. There is not only one proper method always used. That is why this part of constructing a CI is the most discussed and criticised by opponents of CIs (Freudenberg (2003). Weighting methods can be divided into two main groups: statistical approaches and participatory approaches. The most common methods are listed in Nardo et al. (2009). No results from surveys, opinion poll, questionnaires etc. are available and useful for this analysis thus participatory methods cannot be used. This paper deals only with the first group of weighting methods (i.e. statistical methods). These methods are only data driven, that means no subjective value judgments are needed.

Using Equal weighting (EW) method, the equal weight is assigned for each indicator (according to equation (6))

$$
w_{p}=1 / p,
$$

where $w_{p}$ is a weight for $p^{\text {th }}$ indicator $(p=1, \ldots, P)$ for each district. It means all indicators are given the same weight for all LAU 1 regions. Equal weighting may be justified when there is no clear idea which method should be used. The main strength of EW method is definitely its simplicity. On one hand this approach is easy and clear, on the other hand, there is a risk that a pillar with more indicators will have a higher influence on the CI.

Weighting derived from principal component analysis (PCA) and factor analysis (FA) respectively deals with this issue. Both methods are very often used for data explanatory analysis. The PCA and FA explain the variance of the data through a few factors which are formed as a linear combinations of raw data. The original correlated set of indicators is changed into a new smaller set of uncorrelated variables. A detailed description of both methods can be found in e.g. Manly (2004), Morrison (2005), as well as in textbooks or handbooks about statistical software (e.g. StatSoft (2011)). In this analysis we carried out main components extraction and varimax rotation. Weights derived from the PCA are based on eigenvalues. After obtaining them it is necessary to decide about optimal number of components. Kaiser criterion suggests selecting all components which are associated to eigenvalues higher than one. Applying that criterion, in the economic and environmental pillars four factors sufficed, in social pillar five factors were covered into 
further computations. To obtain FA derived weights we followed approach proposed by Nicoletti et al. (1999). The weights had to be normalized by squared factor loadings, which are derived as portions of variance of the factor explained by particular variable. At the end they were scaled to unity sum. The main idea behind the usage of FA derived weights is correction of correlated indicators. Two highly correlated indicators are given lower weight because it is assumed that they can measure the same phenomenon. It is necessary to check the data for correlations before applying the weights on indicators, which was consistently done in section 1 . But this method aims at further correcting of correlation.

The third step in the procedure of CI construction is aggregation. In practice linear aggregation (LIN) is the most widespread. The simplest method represents the weighted average as shown in equation (7), subject to conditions (8).

$$
\begin{aligned}
& C I_{n}=\sum_{p=1}^{p} I_{p n} \cdot w_{p}, \\
& \sum_{p} w_{p}=1 \text { and } 0 \leq w_{p} \leq 1,
\end{aligned}
$$

where $I_{p n}$ is a normalized indicator $p(p=1, \ldots, P)$ for district $n(n=1, \ldots, N)$ and $w_{p}$ weight for indicator $p(p=1, \ldots, P)$. The fundamental topic of the aggregation is compensability among indicators. Linear aggregation implies full compensability, i.e. poor performance in one indicator can be compensated by sufficiently high values of others indicators. Compensability between indicators can be desirable only if various indicators are considered as substitutes. Even if full compensability can be weakened by the weighting scheme, another aggregation rules can suppress that.

Geometric aggregation (GEO) is only partially compensable (see formula 9).

$$
C I_{n}=\prod_{p=1}^{p}\left(I_{p n}\right)^{w_{p}},
$$

where $I_{p n}$ is a normalized indicator $p(p=1, \ldots, P)$ for district $n(n=1, \ldots, N)$ and $w_{p}$ weight for indicator $p(p=1, \ldots, P)$. Geometric aggregation rewards districts with higher scores in stronger intensity because marginal utility of an increase in a low score is much higher than in a high score. Hence districts with low scores should prefer a linear rather than a geometric aggregation. The drawback lies in the requirement of strictly positive values of normalised indicators (i.e. $I_{p n}>1$ ) which means it is not applicable on normalized data by means of z-scores.

As it was already stated, aggregation was done in two steps - firstly within the pillar and after that aggregation of the three pillars. By applying above mentioned techniques we constructed ten different composite indicators. Table 5 shows all ten tested combinations. 
List of 10 tested combinations

\begin{tabular}{l|c|c|c|c}
\hline & Normalization & Weighting & Aggregation in pillar & $\begin{array}{c}\text { Aggregation of three pillars } \\
\text { (without weights) }\end{array}$ \\
\hline CI_1 & Min-max & EW & Arithmetic mean & Arithmetic mean \\
CI_2 & Min-max & EW & Arithmetic mean & Geometric mean \\
CI_3 & Min-max & EW & Geometric mean & Arithmetic mean \\
CI_4 & Min-max & EW & Geometric mean & Geometric mean \\
CI_5 & Min-max & PCA/FA & Arithmetic mean & Arithmetic mean \\
CI_6 & Min-max & PCA/FA & Arithmetic mean & Geometric mean \\
CI_7 & Min-max & PCA/FA & Geometric mean & Arithmetic mean \\
CI_8 & Min-max & PCA/FA & Geometric mean & Geometric mean \\
CI_9 & z-scores & EW & Arithmetic mean & Arithmetic mean \\
CI_10 & z-scores & PCA/FA & Arithmetic mean & Arithmetic mean
\end{tabular}

Source: Own construction.

Note: EW stands for equal weights within the pillars, PCA/FA for weights derived from principal component analysis and factor analysis.

More techniques were used in order to assess the robustness of ranking. We are aware of the fact that this is not the exhaustive list of techniques for normalization, weighting and aggregation. Our aim was to select only methods which are simple, easily understandable and only data driven. Used methods cover two main issues during constructing a composite indicator - correlation and compensability between various indicators (Paruolo et al., 2013). The differences in results as well as suitability of each $\mathrm{CI}$ are discussed in the next section.

\section{Computations, results and discussion}

This section introduces the main results. After normalisation of an indicator, the ranking of the districts remains the same regardless of chosen method of normalisation (min-max or z-scores). However, the values are different and further analyses are influenced by the chosen normalisation method.

Even more important is the weighting scheme. Table 6 shows weights derived from equal weighting and PCA/FA weighting within each pillar. 
Equal and PCA/FA weights within one pillar (in \%)

\begin{tabular}{l|r|r|r|r|r|r|r|r}
\hline Economic pillar & EW & PCA/FA & $\begin{array}{c}\text { Social } \\
\text { pillar }\end{array}$ & EW & PCA/FA & $\begin{array}{c}\text { Environme } \\
\text { ntal pillar }\end{array}$ & EW & PCA/FA \\
\hline EC1 & 7.69 & 4.10 & SO1 & 5.88 & 4.53 & EN1 & 7.69 & 10.82 \\
EC2 & 7.69 & 3.27 & SO2 & 5.88 & 8.36 & EN2 & 7.69 & 10.42 \\
EC3 & 7.69 & 9.71 & SO3 & 5.88 & 5.83 & EN3 & 7.69 & 3.85 \\
EC4 & 7.69 & 4.94 & SO4 & 5.88 & 4.15 & EN4 & 7.69 & 11.60 \\
EC5 & 7.69 & 5.23 & SO5 & 5.88 & 3.39 & EN5 & 7.69 & 10.41 \\
EC6 & 7.69 & 7.24 & SO6 & 5.88 & 5.32 & EN6 & 7.69 & 6.16 \\
EC7 & 7.69 & 10.00 & SO7 & 5.88 & 6.73 & EN7 & 7.69 & 6.81 \\
EC8 & 7.69 & 8.86 & SO8 & 5.88 & 8.45 & EN8 & 7.69 & 0.64 \\
EC9 & 7.69 & 7.05 & SO9 & 5.88 & 9.48 & EN9 & 7.69 & 9.68 \\
EC10 & 7.69 & 9.73 & SO10 & 5.88 & 9.46 & EN10 & 7.69 & 9.82 \\
EC11 & 7.69 & 11.09 & SO11 & 5.88 & 8.69 & EN11 & 7.69 & 8.75 \\
EC12 & 7.69 & 9.55 & SO12 & 5.88 & 1.47 & EN12 & 7.69 & 7.98 \\
EC13 & 7.69 & 9.21 & SO13 & 5.88 & 3.75 & EN13 & 7.69 & 3.05 \\
& & & SO14 & 5.88 & 5.58 & & &
\end{tabular}

Source: Own computation.

Note: EW stands for equal weights, PCA/FA for weights derived from principal component analysis and factor analysis.

In the third step it was essential to decide about the most proper aggregation methods inside a pillar and of all three pillars. For aggregation within a pillar we used the weights computed in Table 6. We calculated all ten CIs presented in Table 5, i.e. all possible combinations of aggregation methods. However, we can conclude that especially geometric aggregation at pillar level produced unreliable results. Therefore, as a final ranking we decided to use combination recommended by Joint Research Centre ${ }^{\mathrm{g}}$. Tarantola (2011) suggests using arithmetic average to combine indicators within a pillar and geometric average to merge pillars into one single composite indicator. The idea is simple: within one pillar there can be considered trade-off between indicators but the pillars should not be fully compensable. Final ranking in Table 7 is based on min-max normalization, weighted arithmetic average at pillar level and geometric average for combining three pillars. Two combinations meet these conditions, one with equal weights (CI_2) and one with PCA/FA weights (CI_6). Results for these two CIs are shown in Table 6. Unlike in cluster analysis in section 2, here is the capital city of Prague (Hlavní město Praha, hereinafter Prague) included in order to bring complete ranking of Czech districts. Number of cluster corresponds with results in section 2 (Prague was labelled as Cluster 7).

g Joint Research Centre provides scientific and technological support to European Union policies. It's Econometrics and Applied Statistics Unit aims besides other issues as well at composite indicators and ranking systems (see http://ipsc.jrc.ec.europa.eu/). 
Final rankings (including Prague)

\begin{tabular}{|c|c|c|c|c|c|c|c|}
\hline & Cluster & EW & PCA/FA & & Cluster & EW & PCA/FA \\
\hline Hlavní město Praha & $\mathrm{C} 7$ & 1 & 1 & Most & $\mathrm{C} 2$ & 40 & 55 \\
\hline Brno-město & C6 & 2 & 2 & Ústí nad Orlicí & $\mathrm{C} 3$ & 41 & 37 \\
\hline Ústí nad Labem & $\mathrm{C} 2$ & 3 & 8 & Sokolov & $\mathrm{C} 2$ & 42 & 40 \\
\hline Praha-západ & $\mathrm{C} 5$ & 4 & 3 & Náchod & $\mathrm{C} 3$ & 43 & 29 \\
\hline Nový Jičín & $\mathrm{C} 1$ & 5 & 6 & Tachov & $\mathrm{C} 4$ & 44 & 50 \\
\hline Zlín & $\mathrm{C} 1$ & 6 & 5 & Blansko & $\mathrm{C} 3$ & 45 & 54 \\
\hline Karviná & $\mathrm{C} 2$ & 7 & 12 & Znojmo & $\mathrm{C} 1$ & 46 & 43 \\
\hline Plzeň-město & $\mathrm{C} 3$ & 8 & 7 & Trutnov & $\mathrm{C} 3$ & 47 & 36 \\
\hline Olomouc & $\mathrm{C} 1$ & 9 & 10 & Prostějov & $\mathrm{C} 1$ & 48 & 56 \\
\hline Hradec Králové & $\mathrm{C} 5$ & 10 & 13 & Jihlava & $\mathrm{C} 3$ & 49 & 41 \\
\hline Liberec & $\mathrm{C} 4$ & 11 & 4 & Kolín & $\mathrm{C} 3$ & 50 & 58 \\
\hline Břeclav & $\mathrm{C} 1$ & 12 & 18 & Žd’ár nad Sázavou & $\mathrm{C} 3$ & 51 & 52 \\
\hline Pardubice & $\mathrm{C} 5$ & 13 & 14 & Rychnov nad Kněžnou & $\mathrm{C} 3$ & 52 & 47 \\
\hline Česká Lípa & $\mathrm{C} 4$ & 14 & 19 & Bruntál & $\mathrm{C} 4$ & 53 & 60 \\
\hline Uherské Hradiště & $\mathrm{C} 1$ & 15 & 20 & Jičín & $\mathrm{C} 3$ & 54 & 51 \\
\hline Praha-východ & $\mathrm{C} 5$ & 16 & 11 & Tábor & $\mathrm{C} 3$ & 55 & 44 \\
\hline Brno-venkov & $\mathrm{C} 1$ & 17 & 21 & Český Krumlov & $\mathrm{C} 4$ & 56 & 46 \\
\hline Cheb & $\mathrm{C} 4$ & 18 & 9 & Svitavy & $\mathrm{C} 3$ & 57 & 62 \\
\hline Ostrava-město & C6 & 19 & 45 & Semily & $\mathrm{C} 3$ & 58 & 49 \\
\hline Litoměřice & $\mathrm{C} 3$ & 20 & 27 & Šumperk & $\mathrm{C} 4$ & 59 & 61 \\
\hline Opava & $\mathrm{C} 1$ & 21 & 15 & Domažlice & $\mathrm{C} 3$ & 60 & 63 \\
\hline Mladá Boleslav & $\mathrm{C} 5$ & 22 & 33 & Benešov & $\mathrm{C} 3$ & 61 & 48 \\
\hline Vyškov & $\mathrm{C} 1$ & 23 & 26 & Jindřichův Hradec & $\mathrm{C} 3$ & 62 & 57 \\
\hline Frýdek-Místek & $\mathrm{C} 4$ & 24 & 24 & Louny & $\mathrm{C} 3$ & 63 & 66 \\
\hline Kladno & $\mathrm{C} 3$ & 25 & 35 & Havlíčkův Brod & $\mathrm{C} 3$ & 64 & 65 \\
\hline Přerov & $\mathrm{C} 1$ & 26 & 30 & Rokycany & $\mathrm{C} 3$ & 65 & 70 \\
\hline Hodonín & $\mathrm{C} 1$ & 27 & 38 & Příbram & $\mathrm{C} 3$ & 66 & 59 \\
\hline Vsetín & $\mathrm{C} 4$ & 28 & 31 & Třebíč & $\mathrm{C} 3$ & 67 & 74 \\
\hline Mělník & $\mathrm{C} 3$ & 29 & 28 & Chrudim & $\mathrm{C} 3$ & 68 & 71 \\
\hline Beroun & $\mathrm{C} 3$ & 30 & 32 & Plzeň-sever & $\mathrm{C} 3$ & 69 & 69 \\
\hline Kroměříž & $\mathrm{C} 1$ & 31 & 39 & Klatovy & $\mathrm{C} 3$ & 70 & 64 \\
\hline Děčín & $\mathrm{C} 4$ & 32 & 25 & Prachatice & $\mathrm{C} 4$ & 71 & 73 \\
\hline Teplice & $\mathrm{C} 2$ & 33 & 42 & Pelhřimov & $\mathrm{C} 3$ & 72 & 67 \\
\hline Jeseník & $\mathrm{C} 4$ & 34 & 16 & Kutná Hora & $\mathrm{C} 3$ & 73 & 72 \\
\hline Karlovy Vary & $\mathrm{C} 4$ & 35 & 22 & Písek & $\mathrm{C} 3$ & 74 & 68 \\
\hline Chomutov & $\mathrm{C} 2$ & 36 & 53 & Plzeň-jih & $\mathrm{C} 5$ & 75 & 76 \\
\hline České Budějovice & $\mathrm{C} 5$ & 37 & 23 & Rakovník & $\mathrm{C} 3$ & 76 & 75 \\
\hline Nymburk & $\mathrm{C} 3$ & 38 & 34 & Strakonice & $\mathrm{C} 3$ & 77 & 77 \\
\hline Jablonec nad Nisou & $\mathrm{C} 4$ & 39 & 17 & & & & \\
\hline
\end{tabular}

Source: Own calculation.

Note: EW stands for equal weights within the pillars, PCA/FA for weights derived from principal component analysis and factor analysis. 
We can see that Prague is at the first place in both cases. This might be a little bit surprising, because capital cities usually perform economically good, do not have so many social problems (low unemployment, high pensions, high life expectancy etc.), but the environmental pillar may not perform so good. Brno as the second biggest Czech city occupies second place. The main surprise for us was the third place of Ústí nad Labem district, because this district is in the long term connected with damaged environment and social problems with higher unemployment. On the other hand, quite a disproportion can be seen in case of Ostrava-město (ranked $19^{\text {th }}$ and $45^{\text {th }}$ ), which was supposed to perform rather worse being a structurally affected LAU 1 region. In case of equal weights probably compensability of indicators causes relatively high ranking of this district.

The remaining rankings including Prague (for CI_1, CI_5, CI_9 and CI_10) are introduced in Appendix 2. All rankings (6 CIs) excluding Prague are listed in Appendix 3.

In order to summarize all results we decided to evaluate 77 Czech districts from the point of view of clusters established in section 2. Median seemed to be a suitable indicator for this target properly eliminating outlying values. Table 8 shows the outcomes including and excluding Prague (Cluster 7).

Cluster medians

Table 8

\begin{tabular}{c|c|c}
\hline Cluster & Including Prague & Excluding Prague \\
\hline C1 & 20.0 & 19.5 \\
C2 & 40.0 & 39.0 \\
C3 & 55.5 & 55.0 \\
C4 & 34.5 & 34.5 \\
C5 & 14.5 & 11.5 \\
C6 & 10.5 & 6.0 \\
C7 & 1.0 & $\mathrm{x}$
\end{tabular}

Source: Own calculation.

The resulting district rankings are not generally unexpected. Districts belonging to the same cluster very often reach similar ranking, i.e. in the overall order they are ranked close to each other. Considering cluster medians, Prague (C7) achieves the first place, followed by big cities (C6), which benefit from the fact that they usually perform well in two pillars (economic and social) having slightly worse results in the third (environmental) pillar. Districts classified to cluster C5 are surroundings of big cities, districts with smaller university cities or prospering industrial branches, so there is no astonishment this cluster is ranked the third. The fourth place take Moravian districts (C1) which have a slightly better performance in environmental pillar, there is lower share of bigger cities and they are more focused on agriculture. Clusters $\mathrm{C} 2$ and $\mathrm{C} 4$ (both border regions) have almost the same results; their common disadvantage can be seen in the distance from centres of economic performance. The worst result achieved cluster C3. The reason for this may lie in the fact that this cluster covers many diverse regions, i.e. when dividing the indicators into pillars this may play an important role.

Comparing the results when both including and excluding Prague brings almost no differences. Only small changes in values can be noticed in C6 and C5 when Prague is 
not part of the analysis. The differences are caused by definition of used methods which are endogenous.

\section{Conclusion}

As we aimed at the analysis of LAU 1 regions, we had to decide, how to assess sustainability there. Finally we chose useful indicators, though different from indicators used at the national or NUTS 3 level, with data available for all LAU 1 regions. We succeeded in filling all three pillars of sustainable development (economic, social and environmental) with sufficient number of suitable indicators. We found coherences among LAU 1 regions that were affected by similar problems. Cluster analysis was applied and six quite homogeneous clusters were identified (seven when including Prague respectively). After that, all 77 districts were ranked (both including and excluding Prague) according to sustainable development. Several normalisation and aggregation methods were used to compare selected indicators having diverse units of measurement. The results show the ranking of LAU 1 regions in the Czech Republic from the economic, social and environmental point of view (i.e. these three perspectives are aggregated into composite indicator). It was proved that the results obtained from cluster analysis performed in section 2 (all indicators together) correspond with the final rankings based on composite indicators computation (indicators separated into corresponding pillars).

Although we obtained exact rankings, our aim was to assess approximate rankings of the districts. The results should indicate the rough position of particular district among all other districts. Each method gives slightly different results, the suitability should be determined according to the aim of single analysis, i.e. if we want rather to assign the equal weights to all indicators or take into account correlations among indicators. In the same way the compensability when choosing the proper aggregation method should be considered. The proper methodological approach (i.e. proper composite indicator) should be selected according to specific requirements of the analysis.

Finally, it is necessary to add, that statistical approach to sustainable development (analysis of indicators) performed in this paper represents just one possible perspective. It may not (and usually does not) fully correspond with the feelings of people in the regions or with their subjective assessment of quality of their lives (different from sustainable development). Such analysis would exceed this paper, not only due to the necessity of vast time- and cost-demanding research and qualitative analysis of questionnaires or indepth interviews but also due to uncertain data representativeness.

\section{REFERENCES}

Burns, R. B. - Burns, R. A. (2009): Additional advanced chapters, Chapter 23, Cluster Analysis: 552-567. In: Business Research Methods and Statistics Using SPSS. Sage Publications Ltd.

Byrch, C. - Kearins, K. - Milne, M. J. - Morgan, R. K. (2009): Sustainable Development: What does it really mean? University of Auckland Business Review, 11 (1): 1-7.

Cambridge Econometrics (2013): Data Definitions. [online]. Cambridge Econometrics, Cambridge. [cit. 201306-24]. 
$<$ http://www.camecon.com/Europe/Regional_Local_Cities/KnowledgeBase/Appendices/EuRegM /Data_Definitions.aspx>.

Ciegis, R. - Ramanauskiene, J. - Martinkus, B. (2009): The Concept of Sustainable Development and its Use for Sustainability Scenarios. Engineering Economics, 62 (2): 28-37.

Czech Statistical Office (2012): Statistical Yearbook of the Czech Republic 2012. Český statistický úřad, Praha.

Czech Statistical Office (2010): Vybrané oblasti udržitelného rozvoje v krajích České republiky 2010 [Selected Areas of Sustainable Development in the Regions of the Czech Republic 2010]. Český statistický úřad, Praha.

Czesaný, S. (2006): Indikátory udržitelného rozvoje [Sustainable Development Indicators]. Statistika, 43 (5): 431-434.

European Commission (2013): European Common Indicators. [online]. European Commission, Bruxelles/ Luxembourg. [cit. 2013-06-20]. http://ec.europa.eu/environment/urban/common indicators.htm.

EUROSTAT (2013): Sustainable Development Indicators. [online]. EUROSTAT, Luxembourg. [cit. 2013-0620]. <http://epp.eurostat.ec.europa.eu/portal/page/portal/sdi/indicators $>$.

Fischer, J. - Helman, K. - Kramulová, J. - Petkovová, L. - Zeman, J. (2013): Sustainable development indicators at the regional level in the Czech Republic. Statistika, 93 (1): 5-18.

Freudenberg, M. (2003): Composite Indicators of Country Performance: A Critical Assessment. OECD Science, Technology and Industry Working Papers, 2003/16, OECD Publishing.

Government Council for Sustainable Development - Ministry of the Environment (2009): Progress Report on the Czech Republic Sustainable Development Strategy. Summary. Praha.

Government Council for Sustainable Development - Ministry of the Environment (2012): Progress Report on the Czech Republic's Strategic Framework for Sustainable Development. Praha.

Hebák, P. - Hustopecký, J. - Pecáková, I. - Plašil, M. - Průša, M. - Řezanková, H. - Vlach, P. - Svobodová, A. (2007): Vicerozmérné statistické metody [3] [Multi-dimensional Statistical Methods [3]]. Informatorium, Praha.

Klugman, J. (2011): Human Development Report 2011. Sustainability and Equity: A Better Future for All. United Nations Development Programme, New York.

Lengyel, I. - Szakálné Kanó, I. (2012): Competitiveness of Hungarian Urban Micro-regions: Localization Agglomeration Economies and Regional Competitiveness Function. Regional Statistics, Special Issue, 52 (2): 27-44.

Macháček, J. (2004): Ekonomické souvislosti využivání kulturně historických lokalit [Economical Context of Taking Advantage of Cultural Historical Localities]. Oeconomica, Praha.

Manly, B. F. J. (2004): Multivariate statistical methods: A primer. Chapman and Hall/CRC, London.

Marsden, G. - Kimble, M. - Nellthorp, J. - Kelly, C. (2010): Sustainability Assessment: The Definition Deficit. International Journal of Sustainable Transportation, 4 (4): 189-211.

Mederly, P. - Topercer, J. - Nováček, P. (2004): Indikátory kvality života a udržitelného rozvoje - kvantitativní, vicerozměrný a variantni př́stup [Indicators of Quality of Life and Sustainable DevelopmentQuantitative, Multidimensional and Alternative Approach]. UK FSV CESES, Praha.

Mimmack, G. M. - Mason, S. J. - Galpin, J. S. (2001): Choice of Distance Matrices in Cluster Analysis: Defining Regions. Journal of Climate. 14 (12): 2790-2797.

Mooi, E. - Sarstedt, A. (2011): Cluster Analysis: 237-284. In: A Concise Guide to Market Research. SpringerVerlag, Berlin Heidelberg.

Ministry of Environment - Czech Statistical Office - CENIA (2006): Statistical Environmental Yearbook of the Czech Republic 2006. Praha.

Morrison, D. F. (2005): Multivariate Statistical Methods. Thompson Brooks, California.

Nardo, M. - Saisana, M. - Saltelli, A. - Tarantola, S. - Hoffman, H. - Giovannini, E. (2009): Handbook on constructing composite indicators: methodology and user guide. OECD, Paris.

Nicoletti, G. - Scarpetta, S. - Boylaud, O. (1999): Summary indicators of product market regulation with an extension to employment protection legislation. Economic Department Working Papers. No. 226. OECD, Paris.

Nováček, P. - Mederly, P. (1996): Strategie udržitelného rozvoje [Sustainable Development Strategy]. G plus G, Praha.

Odehnal, J. - Sedlaik, M. - Michalek, J. (2012): A Competitiveness Evaluation of the Ukrainian Regions Empirical Study. Engineering Economics. 23 (4): 406-413. 
Office for National Statistics (2013): NUTS: London Directory. [online]. Office for National Statistics, UK. [cit. 2013-06-24]. <http://www.ons.gov.uk/ons/guide-method/geography/ beginner-sguide/eurostat/london/index.html $>$.

Parris, T. M. - Kates, R. W. (2003): Characterizing and measuring sustainable development. Annual Review of environment and resources. 28 (1): 559-586.

Paruolo, P. - Saisana, M. - Saltelli, A. (2013): Ratings and rankings: voodoo or science? Journal of the Royal Statistical Society: Series A (Statistics in Society). 176 (3): 609-634.

Rassafi, A. A. - Poorzahedy, H. - Vaziri, M. (2006): An alternative definition of sustainable development using stability and chaos theories. Sustainable Development, 14 (1): 62-71.

StatSoft, Inc. (2011): Electronic Statistics Textbook. (Electronic Version). StatSoft. Available at: www.statsoft.com/textbook

Tarantola, S. (2011): Aggregation rules. Lecture at JRC Seminar on Composite Indicators and Rankings. Ispra, Italy.

TIMUR. (2012): Týmová iniciativa pro místní udržitelný rozvoj [Team Initiative for Local Sustainable Development]. [online]. Timur, Praha. [cit. 2012-09-30]. <http://www.timur.cz/>.

WCED. (1987): Our Common Future. Oxford University Press, Oxford.

\section{Acknowledgements}

This paper was prepared under the support of the University of Economics in Prague, project No. 11/2012 "Construction and verification of sustainable development indicators in the Czech Republic and its regions". 


\section{Appendix}

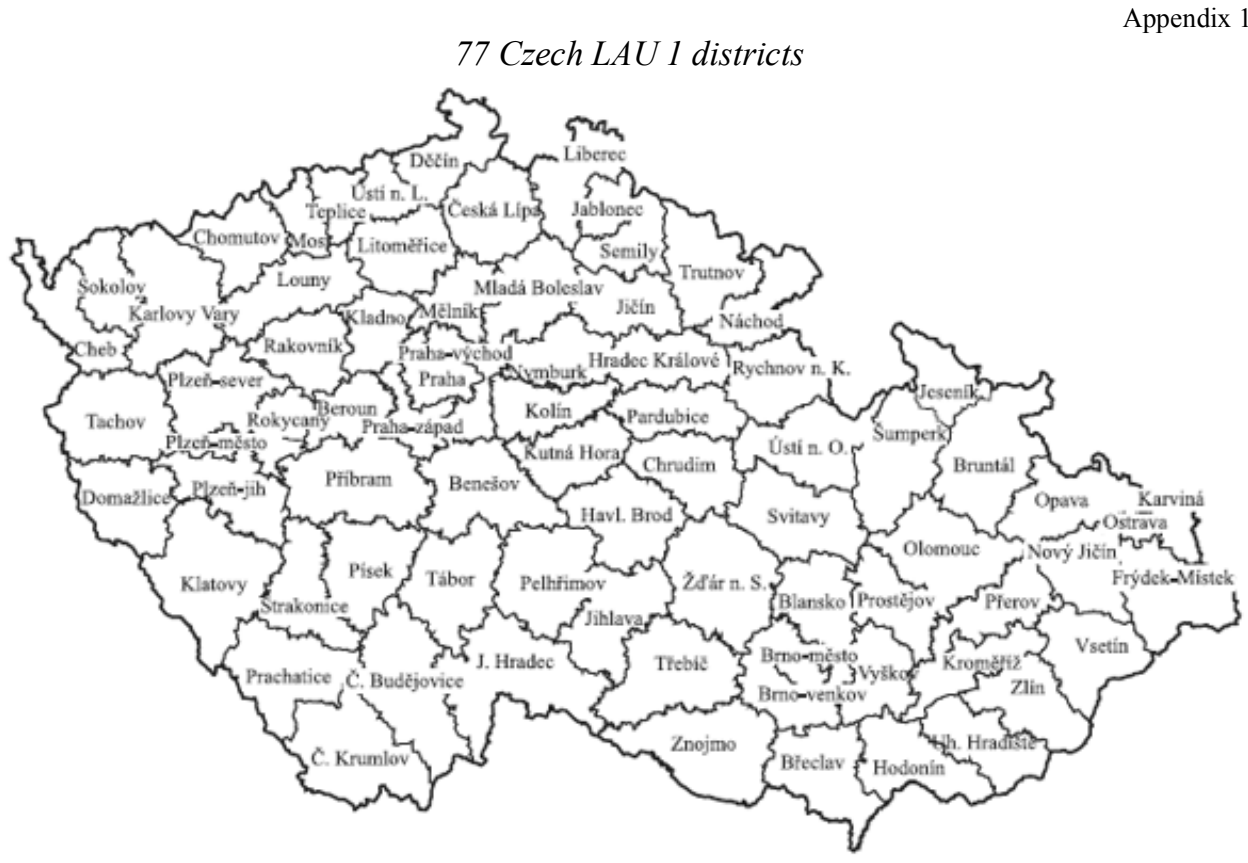

Source: Ministry of Environment et al. (2006). 
Final results of analysis of 77 Czech LAU 1 regions (including Prague)

\begin{tabular}{|c|c|c|c|c|c|}
\hline Cluster & LAU 1 Region & CI_9 & CI_10 & CI_1 & CI_5 \\
\hline $\mathrm{C} 1$ & Břeclav & 6 & 3 & 4 & 8 \\
\hline $\mathrm{C} 1$ & Brno-venkov & 9 & 13 & 9 & 14 \\
\hline $\mathrm{C} 1$ & Hodonín & 21 & 29 & 19 & 24 \\
\hline $\mathrm{C} 1$ & Znojmo & 31 & 27 & 29 & 25 \\
\hline $\mathrm{C} 1$ & Uherské Hradiště & 18 & 20 & 14 & 17 \\
\hline $\mathrm{C} 1$ & Olomouc & 11 & 8 & 11 & 10 \\
\hline $\mathrm{C} 1$ & Zlín & 10 & 7 & 8 & 6 \\
\hline $\mathrm{C} 1$ & Vyškov & 24 & 24 & 20 & 20 \\
\hline $\mathrm{C} 1$ & Nový Jičín & 12 & 10 & 6 & 5 \\
\hline $\mathrm{C} 1$ & Kroměříž & 33 & 43 & 32 & 39 \\
\hline $\mathrm{C} 1$ & Opava & 25 & 18 & 23 & 16 \\
\hline $\mathrm{C} 1$ & Přerov & 32 & 38 & 30 & 34 \\
\hline $\mathrm{C} 1$ & Prostějov & 52 & 54 & 49 & 49 \\
\hline $\mathrm{C} 2$ & Ústí nad Labem & 5 & 12 & 5 & 11 \\
\hline $\mathrm{C} 2$ & Karviná & 15 & 21 & 13 & 18 \\
\hline $\mathrm{C} 2$ & Sokolov & 42 & 46 & 42 & 51 \\
\hline $\mathrm{C} 2$ & Teplice & 36 & 53 & 39 & 55 \\
\hline $\mathrm{C} 2$ & Chomutov & 35 & 56 & 41 & 60 \\
\hline $\mathrm{C} 2$ & Most & 44 & 68 & 43 & 67 \\
\hline $\mathrm{C} 3$ & Litoměřice & 19 & 25 & 16 & 22 \\
\hline $\mathrm{C} 3$ & Beroun & 23 & 19 & 27 & 21 \\
\hline $\mathrm{C} 3$ & Mělník & 26 & 22 & 28 & 19 \\
\hline $\mathrm{C} 3$ & Kladno & 22 & 30 & 26 & 32 \\
\hline $\mathrm{C} 3$ & Náchod & 41 & 31 & 35 & 28 \\
\hline $\mathrm{C} 3$ & Blansko & 46 & 55 & 44 & 56 \\
\hline $\mathrm{C} 3$ & Kolín & 45 & 47 & 48 & 48 \\
\hline $\mathrm{C} 3$ & Jindřichův Hradec & 55 & 51 & 55 & 50 \\
\hline $\mathrm{C} 3$ & Ústí nad Orlicí & 37 & 37 & 36 & 38 \\
\hline $\mathrm{C} 3$ & Chrudim & 64 & 64 & 59 & 63 \\
\hline $\mathrm{C} 3$ & Třebíč & 62 & 65 & 58 & 64 \\
\hline $\mathrm{C} 3$ & Žd’ár nad Sázavou & 53 & 48 & 50 & 44 \\
\hline $\mathrm{C} 3$ & Rychnov nad Kněžnou & 48 & 39 & 47 & 40 \\
\hline $\mathrm{C} 3$ & Nymburk & 39 & 34 & 37 & 36 \\
\hline $\mathrm{C} 3$ & Jičín & 54 & 52 & 51 & 47 \\
\hline $\mathrm{C} 3$ & Plzeň-město & 7 & 6 & 12 & 9 \\
\hline $\mathrm{C} 3$ & Jihlava & 50 & 40 & 53 & 42 \\
\hline $\mathrm{C} 3$ & Rokycany & 58 & 63 & 62 & 66 \\
\hline $\mathrm{C} 3$ & Havlíčkův Brod & 66 & 58 & 65 & 58 \\
\hline C3 & Rakovník & 75 & 74 & 74 & 74 \\
\hline $\mathrm{C} 3$ & Svitavy & 61 & 61 & 57 & 57 \\
\hline
\end{tabular}




\begin{tabular}{|c|c|c|c|c|c|}
\hline Cluster & LAU 1 Region & CI_9 & CI_10 & CI_1 & CI_5 \\
\hline $\mathrm{C} 3$ & Benešov & 56 & 44 & 56 & 46 \\
\hline $\mathrm{C} 3$ & Klatovy & 71 & 59 & 71 & 59 \\
\hline $\mathrm{C} 3$ & Domažlice & 60 & 60 & 61 & 61 \\
\hline $\mathrm{C} 3$ & Trutnov & 51 & 41 & 52 & 41 \\
\hline $\mathrm{C} 3$ & Semily & 59 & 49 & 60 & 45 \\
\hline $\mathrm{C} 3$ & Louny & 70 & 75 & 67 & 72 \\
\hline $\mathrm{C} 3$ & Plzeň-sever & 63 & 62 & 68 & 69 \\
\hline $\mathrm{C} 3$ & Kutná Hora & 73 & 70 & 73 & 71 \\
\hline $\mathrm{C} 3$ & Tábor & 57 & 50 & 63 & 52 \\
\hline $\mathrm{C} 3$ & Pelhřimov & 74 & 66 & 75 & 68 \\
\hline $\mathrm{C} 3$ & Příbram & 67 & 57 & 70 & 65 \\
\hline $\mathrm{C} 3$ & Strakonice & 77 & 77 & 77 & 77 \\
\hline $\mathrm{C} 3$ & Písek & 76 & 73 & 76 & 75 \\
\hline $\mathrm{C} 4$ & Česká Lípa & 17 & 23 & 18 & 30 \\
\hline $\mathrm{C} 4$ & Vsetín & 30 & 36 & 31 & 33 \\
\hline $\mathrm{C} 4$ & Frýdek-Místek & 27 & 33 & 25 & 31 \\
\hline $\mathrm{C} 4$ & Český Krumlov & 49 & 42 & 54 & 43 \\
\hline $\mathrm{C} 4$ & Prachatice & 68 & 71 & 69 & 73 \\
\hline $\mathrm{C} 4$ & Liberec & 16 & 4 & 17 & 4 \\
\hline $\mathrm{C} 4$ & Děčín & 38 & 35 & 34 & 35 \\
\hline $\mathrm{C} 4$ & Cheb & 20 & 14 & 24 & 13 \\
\hline $\mathrm{C} 4$ & Tachov & 40 & 45 & 46 & 54 \\
\hline $\mathrm{C} 4$ & Šumperk & 69 & 67 & 66 & 62 \\
\hline $\mathrm{C} 4$ & Jeseník & 43 & 32 & 38 & 26 \\
\hline $\mathrm{C} 4$ & Jablonec nad Nisou & 47 & 28 & 45 & 27 \\
\hline $\mathrm{C} 4$ & Bruntál & 65 & 72 & 64 & 70 \\
\hline $\mathrm{C} 4$ & Karlovy Vary & 34 & 26 & 40 & 37 \\
\hline $\mathrm{C} 5$ & Praha-západ & 3 & 3 & 3 & 3 \\
\hline $\mathrm{C} 5$ & Hradec Králové & 8 & 11 & 7 & 12 \\
\hline $\mathrm{C} 5$ & Praha-východ & 4 & 5 & 10 & 7 \\
\hline $\mathrm{C} 5$ & Pardubice & 13 & 15 & 15 & 15 \\
\hline $\mathrm{C} 5$ & České Budějovice & 28 & 16 & 33 & 23 \\
\hline C5 & Mladá Boleslav & 14 & 17 & 21 & 29 \\
\hline $\mathrm{C} 5$ & Plzeň-jih & 72 & 76 & 72 & 76 \\
\hline C6 & Brno-město & 2 & 2 & 2 & 2 \\
\hline C6 & Ostrava-město & 29 & 69 & 22 & 53 \\
\hline $\mathrm{C} 7$ & Hlavní město Praha & 1 & 1 & 1 & 1 \\
\hline
\end{tabular}

Source: Own computation. 
Final results of analysis of 77 Czech LAU 1 regions (excluding Prague)

\begin{tabular}{|c|c|c|c|c|c|c|c|}
\hline Cluster & LAU 1 Region & CI_9 & CI_10 & CI_1 & CI_5 & CI_2 & CI_6 \\
\hline $\mathrm{C} 1$ & Zlín & 5 & 6 & 3 & 3 & 5 & 4 \\
\hline $\mathrm{C} 1$ & Olomouc & 7 & 7 & 9 & 5 & 6 & 6 \\
\hline $\mathrm{C} 1$ & Brno-venkov & 8 & 11 & 6 & 11 & 11 & 15 \\
\hline $\mathrm{C} 1$ & Břeclav & 10 & 13 & 4 & 15 & 9 & 16 \\
\hline $\mathrm{C} 1$ & Nový Jičín & 12 & 12 & 12 & 7 & 8 & 7 \\
\hline $\mathrm{C} 1$ & Uherské Hradiště & 18 & 19 & 15 & 16 & 18 & 19 \\
\hline $\mathrm{C} 1$ & Hodonín & 23 & 27 & 20 & 25 & 22 & 36 \\
\hline $\mathrm{C} 1$ & Opava & 25 & 18 & 22 & 20 & 17 & 17 \\
\hline $\mathrm{C} 1$ & Vyškov & 28 & 28 & 25 & 26 & 28 & 31 \\
\hline $\mathrm{C} 1$ & Přerov & 31 & 37 & 29 & 27 & 34 & 33 \\
\hline $\mathrm{C} 1$ & Znojmo & 32 & 29 & 32 & 45 & 31 & 44 \\
\hline $\mathrm{C} 1$ & Kroměříž & 34 & 41 & 31 & 30 & 39 & 39 \\
\hline $\mathrm{C} 1$ & Prostějov & 51 & 56 & 48 & 48 & 53 & 54 \\
\hline $\mathrm{C} 2$ & Ústí nad Labem & 9 & 14 & 5 & 4 & 13 & 9 \\
\hline $\mathrm{C} 2$ & Karviná & 15 & 17 & 13 & 9 & 16 & 13 \\
\hline $\mathrm{C} 2$ & Chomutov & 33 & 53 & 38 & 35 & 56 & 48 \\
\hline $\mathrm{C} 2$ & Teplice & 35 & 49 & 35 & 32 & 47 & 41 \\
\hline $\mathrm{C} 2$ & Sokolov & 40 & 48 & 41 & 40 & 51 & 43 \\
\hline $\mathrm{C} 2$ & Most & 42 & 61 & 43 & 41 & 64 & 58 \\
\hline $\mathrm{C} 3$ & Plzeň-město & 3 & 3 & 8 & 6 & 4 & 5 \\
\hline $\mathrm{C} 3$ & Litoměřice & 20 & 26 & 17 & 19 & 24 & 26 \\
\hline $\mathrm{C} 3$ & Kladno & 22 & 24 & 23 & 23 & 29 & 25 \\
\hline $\mathrm{C} 3$ & Beroun & 26 & 22 & 27 & 31 & 25 & 32 \\
\hline $\mathrm{C} 3$ & Mělník & 27 & 25 & 28 & 29 & 23 & 29 \\
\hline $\mathrm{C} 3$ & Ústí nad Orlicí & 36 & 32 & 34 & 36 & 37 & 35 \\
\hline $\mathrm{C} 3$ & Náchod & 39 & 30 & 37 & 38 & 30 & 28 \\
\hline $\mathrm{C} 3$ & Nymburk & 41 & 39 & 39 & 39 & 38 & 38 \\
\hline $\mathrm{C} 3$ & Kolín & 43 & 50 & 46 & 50 & 48 & 55 \\
\hline $\mathrm{C} 3$ & Blansko & 44 & 55 & 42 & 44 & 55 & 52 \\
\hline $\mathrm{C} 3$ & Jihlava & 46 & 36 & 50 & 47 & 41 & 40 \\
\hline $\mathrm{C} 3$ & Rychnov nad Kněžnou & 48 & 42 & 47 & 52 & 42 & 47 \\
\hline $\mathrm{C} 3$ & Trutnov & 49 & 38 & 51 & 46 & 40 & 37 \\
\hline $\mathrm{C} 3$ & Žd’ár nad Sázavou & 50 & 45 & 49 & 49 & 43 & 49 \\
\hline $\mathrm{C} 3$ & Jičín & 53 & 54 & 52 & 53 & 50 & 53 \\
\hline $\mathrm{C} 3$ & Jindřichův Hradec & 54 & 52 & 54 & 59 & 54 & 57 \\
\hline $\mathrm{C} 3$ & Benešov & 55 & 46 & 56 & 57 & 46 & 46 \\
\hline $\mathrm{C} 3$ & Tábor & 56 & 47 & 55 & 51 & 45 & 42 \\
\hline $\mathrm{C} 3$ & Semily & 57 & 51 & 60 & 58 & 52 & 51 \\
\hline $\mathrm{C} 3$ & Svitavy & 58 & 60 & 57 & 55 & 57 & 59 \\
\hline $\mathrm{C} 3$ & Rokycany & 59 & 67 & 63 & 66 & 66 & 71 \\
\hline
\end{tabular}




\begin{tabular}{|c|c|c|c|c|c|c|c|}
\hline Cluster & LAU 1 Region & CI_9 & CI_10 & CI_1 & CI_5 & CI_2 & CI_6 \\
\hline $\mathrm{C} 3$ & Třebíč & 60 & 65 & 58 & 65 & 61 & 68 \\
\hline $\mathrm{C} 3$ & Domažlice & 61 & 62 & 61 & 61 & 63 & 64 \\
\hline $\mathrm{C} 3$ & Chrudim & 62 & 64 & 59 & 67 & 62 & 70 \\
\hline $\mathrm{C} 3$ & Havlíčkův Brod & 63 & 58 & 62 & 62 & 58 & 61 \\
\hline $\mathrm{C} 3$ & Príbram & 64 & 57 & 67 & 63 & 60 & 56 \\
\hline $\mathrm{C} 3$ & Plzeň-sever & 65 & 63 & 69 & 69 & 69 & 67 \\
\hline $\mathrm{C} 3$ & Klatovy & 67 & 59 & 70 & 68 & 59 & 60 \\
\hline $\mathrm{C} 3$ & Louny & 70 & 73 & 66 & 64 & 72 & 66 \\
\hline $\mathrm{C} 3$ & Pelhřimov & 72 & 66 & 73 & 72 & 67 & 65 \\
\hline $\mathrm{C} 3$ & Kutná Hora & 73 & 70 & 72 & 71 & 70 & 72 \\
\hline $\mathrm{C} 3$ & Rakovník & 74 & 74 & 74 & 75 & 74 & 74 \\
\hline $\mathrm{C} 3$ & Písek & 75 & 72 & 75 & 73 & 73 & 69 \\
\hline $\mathrm{C} 3$ & Strakonice & 76 & 76 & 76 & 76 & 76 & 75 \\
\hline $\mathrm{C} 4$ & Liberec & 16 & 4 & 16 & 12 & 3 & 3 \\
\hline $\mathrm{C} 4$ & Česká Lípa & 17 & 23 & 19 & 17 & 26 & 21 \\
\hline $\mathrm{C} 4$ & Frýdek-Místek & 21 & 21 & 18 & 18 & 19 & 18 \\
\hline $\mathrm{C} 4$ & Cheb & 24 & 15 & 24 & 22 & 14 & 11 \\
\hline $\mathrm{C} 4$ & Karlovy Vary & 29 & 20 & 33 & 34 & 27 & 20 \\
\hline $\mathrm{C} 4$ & Vsetín & 30 & 35 & 30 & 28 & 35 & 34 \\
\hline $\mathrm{C} 4$ & Děčín & 37 & 34 & 36 & 33 & 36 & 27 \\
\hline $\mathrm{C} 4$ & Tachov & 38 & 44 & 44 & 42 & 49 & 45 \\
\hline $\mathrm{C} 4$ & Jeseník & 45 & 40 & 40 & 37 & 33 & 23 \\
\hline $\mathrm{C} 4$ & Jablonec nad Nisou & 47 & 31 & 45 & 43 & 32 & 22 \\
\hline $\mathrm{C} 4$ & Český Krumlov & 52 & 43 & 53 & 56 & 44 & 50 \\
\hline $\mathrm{C} 4$ & Bruntál & 66 & 71 & 64 & 54 & 68 & 62 \\
\hline $\mathrm{C} 4$ & Šumperk & 68 & 68 & 65 & 60 & 65 & 63 \\
\hline $\mathrm{C} 4$ & Prachatice & 69 & 69 & 68 & 70 & 71 & 73 \\
\hline $\mathrm{C} 5$ & Praha-západ & 2 & 2 & 2 & 2 & 2 & 2 \\
\hline $\mathrm{C} 5$ & Praha-východ & 4 & 5 & 10 & 14 & 7 & 8 \\
\hline $\mathrm{C} 5$ & Hradec Králové & 6 & 8 & 7 & 8 & 10 & 10 \\
\hline C5 & Pardubice & 11 & 10 & 14 & 10 & 12 & 12 \\
\hline $\mathrm{C} 5$ & Mladá Boleslav & 14 & 16 & 21 & 21 & 21 & 24 \\
\hline $\mathrm{C} 5$ & České Budějovice & 19 & 9 & 26 & 24 & 15 & 14 \\
\hline $\mathrm{C} 5$ & Plzeň-jih & 71 & 75 & 71 & 74 & 75 & 76 \\
\hline C6 & Brno-město & 1 & 1 & 1 & 1 & 1 & 1 \\
\hline C6 & Ostrava-město & 13 & 33 & 11 & 13 & 20 & 30 \\
\hline
\end{tabular}

Source: Own computation. 